\title{
UPAYA PENINGKATAN KEAKTIFAN DAN HASIL BELAJAR SISWA MELALUI METODE CTL PADA MATA PELAJARAN ELEKTRONIKA DI SMP PGRI KARANGJATI NGAWI
}

\author{
Nurulita Imansari ${ }^{1}$, Moh. Tri Maryono ${ }^{2}$ \\ ${ }^{1}$ Prodi Pendidikan Teknik Elektro, FPTK, IKIP PGRI Madiun \\ Madiun, 63118, Indonesia \\ ${ }^{2}$ Prodi Pendidikan Teknik Elektro, FPTK, IKIP PGRI Madiun \\ Madiun, 63118, Indonesia \\ Email : nurulita.imansari@ikippgrimadiun.ac.id; m3maryono@gmail.com
}

\begin{abstract}
ABSTRAK
Rendahnya keaktifan dan prestasi belajar siswa dalam mata pelajaran Dasar-dasar Elektronika merupakan masalah yang sering muncul dalam pembelajaran Dasar-dasar Elektronika. Hal ini dikarenakan metode pembelajaran yang digunakan guru kurang masih belum mampu membantu siswa dalam meningkatkan keaktifan dan prestasi belajarnya. Pembelajaran melalui metode pembelajaran CTL dapat membuat siswa lebih aktif dan kreatif dalam kegiatan belajar.Penelitian ini bertujuan untuk mengetahui hasil peningkatan keaktifan dan prestasi belajar dasar-dasar elektronika dengan menggunakan metode CTL (Contextual Teaching and Learning). Subyek dari penelitian ini adalah siswa kelas VIII yang berjumlah 28 siswa terdiri dari 12 anak laki-laki dan 16 anak perempuan Pengumpulan data dilakukan dengan menggunakan tes formatif ,Tes dilaksanakan pada akhir siklus. Hasil penelitian menunjukkan bahwa pada keaktifan siklus I 15,82, kemudian pada siklus II 20,78, dan pada tes formatif siklus I 75,35, kemudian pada siklus II 83,92.Berdasarkan hasil penelitian yang telah dilakukan melalui metode CTL (Contextual Teaching and Learning), disimpulkan bahwa metode CTL dapat meningkatkan keaktifan dan prestasi belajar siswa kelas VIII SMP PGRI Karangjati Ngawi
\end{abstract}

Kata Kunci : Metode CTL, Keaktifan Belajar, Prestasi Belajar

\section{Pendahuluan}

Perkembangan ilmu pengetahuan dan teknologi yang kian pesat dan perubahan global dalam berbagai aspek kehidupan yang datang begitu cepat menjadi tantangan bangsa dalam mempersiapkan generasi masa depan, termasuk peserta didik. Untuk menghadapi dinamika dan mengantisipasi persoalan-persoalan kemungkinan besar sudah atau akan terjadi dalam bidang pendidikan perlu disiapkan perangkat aturan atau kurikulum yang berbasis kompetensi. Kompetensi tersebut diharapkan dapat mengembangkan ketrampilan dan keahlian untuk dapat mempertahankan hidup di tengah perubahan dunia yangtiba-tiba, cepat, rumit, tidak pasti dan tidak menentu.

Menurut GBHN tahun 2005 menyatakan bahwa pendidikan nasional selama lima tahun yang akan datang diarahkan untuk mewujudkan system dan iklim pendidikan nasional yang demokratis dan bermutu. Untuk itu mutu pendidikan di Indonesia sekarang ini masih terus diupayakan peningkatannya. Di antara upaya yang dilakukan untuk meningkatkan mutu pendidikan adalah dilaksanakannya program peningkatan mutu pendidikan berbasis sekolah. 
Keberhasilan pendidikan dipengaruhi oleh perubahan dan perbaikan komponen-komponen pendidikan. Perubahan dan perbaikan tersebut meliputi aspek kurikulum, sarana dan prasarana, guru, siswa serta model pembelajaran yang tepat. Salah satu komponen pokok dari pendidikan adalah siswa, sehingga semua kegiatan proses belajar mengajar harus diarahkan kepada keberhasilan siswa.

Bertolak dari masalah ini, guru merupakan salah satu input instrumental yang mentransfer ilmu agar siswa memiliki pengetahuan, ketrampilan dan sikap yang sempurna agar dapat menciptakan kondisi yang menyenangkan di dalam kelas, terutama bagi guru mata pelajaran elektronika. Untuk menciptakan kondisi belajar yang baik di dalam kelas seorang guru dituntut untuk mengetahui, memilih dan menerapkan model pembelajaran yang sesuai dengan kondisi siswa sehingga tujuan pembelajaran dapat tercapai.

SMP PGRI Karangjati termasuk sekolah di Kabupaten Ngawi dan dalam pembelajarannya menggunakan kurikulum KTSP (Kurikulum Tingkat Satuan Pendidikan). Namun kenyataannya berdasarkan pengamatan dan pengalaman guru pengajar Elektro di SMP PGRI Karangjati, masih banyak siswa dalam pembelajaran teknik, khususnya materi Dasar Elektronika masih mengalami kendala dan belum memperoleh hasil yang memuaskan. Hal itu terbukti bahwasanya masih banyak nilai-nilai siswa pada pelajaran Dasar Elektronika yang masih kurang memenuhi SKBM (Standart Ketuntasan Belajar Minimum)

Untuk menyikapi hal tersebut, peneliti mencoba untuk mengadakan penelitian sebagai upaya meningkatkan keaktifan belajar dan prestasi belajar siswa melalui metode CTL (Contextual Teaching and Learning). Model pembelajaran CTL merupakan proses pembelajaran yang holistik dan bertujuan membantu siswa untuk memahami makna materi ajar dengan mengaitkannya terhadap konteks kehidupan mereka sehari-hari (konteks pribadi, sosial dan kultural), sehingga siswa memiliki pengetahuan/ ketrampilan yang dinamis dan fleksibel untuk mengkonstruksi sendiri secara aktif pemahamannya.

CTL dapat membuat siswa terlibat dalam kegiatan yang bermakna yang diharapkan dapat membantu mereka mampu menghubungkan pengetahuan yang diperoleh di kelas dengan konteks situasi kehidupan nyata. Pembelajaran dengan peran serta lingkungan secara alami akan memantapkan pengetahuan yang dimiliki siswa. Belajar akan lebih bermanfaat dan bermakna jika seorang siswa mengalami apa yang dipelajarinya bukan hanya sekedar mengetahui. Belajar tidak hanya sekedar menghafal tetapi siswa harus dapat mengonstruksikan pengetahuan yang dimiliki dengan cara mengaplikasikan pengetahuan yang dimiliki pada realita kehidupan sehari-hari (Contextual Problem).

Dengan diadakannya penelitian ini, diharapkan hasilnya dapat membantu memecahkan persoalanpersoalan dalam proses belajar mengajar Dasar Elektronika, agar kegiatan proses belajar mengajar lebih efektif dan efisien.

Berdasarkan identifikasi masalah di atas dapat dimunculkan rumusan masalah sebagai berikut :

1. Bagaimanakah metode pembelajaran yang digunakan guru agar siswa lebih aktif dalam kegiatan belajar mengajar untuk mata pelajaran Dasar Elektronika kelas VIII SMP PGRI Karangjati Kebupaten Ngawi?

2. Bagaimanakah meningkatkan prestasi belajar siswa pada mata 
pelajaran Dasar Elektronika kelas VIII SMP PGRI Karangjati Kabupaten Ngawi?

Untuk mengatasi masalah di atas, maka peneliti akan menerapkan metode CTL (Contextual Teaching and Learning) untuk meningkatkan keaktifan dan prestasi belajar siswa pada mata pelajaran Dasar Elektronika siswa kelas VIII SMP PGRI Karangjati Kabupaten Ngawi.

\section{Metode Penelitian}

Penelitian ini tergolong dalam penelitian tindakan kelas (Classroom Action Research). Menurut Mills (dalam Wiyono, 2008:1) penelitian tindakan kelas adalah penelitian sistematis yang dilakukan oleh peneliti guru, kepala sekolah atau lainnya tentang situasi belajar mengajar di kelas dengan mengumpulkan informasi tentang praktik-praktik kegiatan sekolah, kegiatan mengajar guru, atau kegiatan belajar siswa dalam rangka untuk memperoleh wawasan, mengembangkan praktik-praktik secara reflektif, serta membawa dampak perubahan positif terhadap sekolah, dan meningkatkan hasil belajar siswa.

Untuk memperoleh data yang sesuai dengan permasalahan dan tujuan penelitian maka penelitian tindakan kelas ini akan dilaksanakan dalam dua siklus. Masing-masing terdiri dari empat tahapan yaitu tahap perencanaan, tahap pelaksanaan tindakan, tahap pengamatan (observasi), dan tahap refleksi. Adapun alur dari penelitian tindakan kelas ini adalah sebagai berikut :

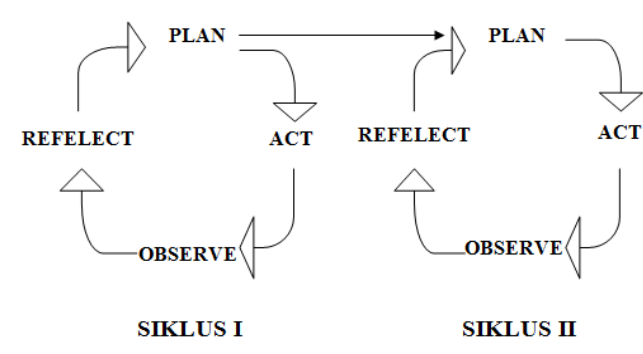

Gambar 1.1 Alur Penelitian Tindakan Kelas.

Sumber : Lewin (dalam Wiyono, 2008:13)

Langkah-langkah penelitian tindakan kelas adalah sebagai berikut :

- Perencanaan

Langkah pertama yang dilakukan dalam penelitian ini adalah langkah perencanaan. Dalam tahap ini, peneliti bersama tim pengajar menetapkan langkah-langkah tindakan yang akan dilakukan dalam proses penelitian. Secara garis besar ada empat hal yang dipersiapkan, yaitu: (1) merencanakan langkahlangkah proses tindakan yang akan dilakukan, (2) mempersiapkan fasilitas dan sarana pendukung yang diperlukan dalam melaksanakan tindakan, (3) mempersiapkan cara melakukan observasi terhadap pelaksanaan tindakan, dan (4) membuat scenario apa yang akan dilakukan dalam melaksanakan tindakan.

- Pelaksanaan tindakan langkah kedua yang akan dilaksanakan dalam penelitian ini adalah tahap pelaksanaan tindakan. Kegiatan utama yang dilaksanakan dalam tahap ini adalah melaksanakan tindakan sesuai dengan rencana yang ditetapkan. Semua kegiatan dilaksanakan sesuai dengan perencanaan tindakan yang telah 
ditetapkan tim peneliti bersama partisipan.

- Observasi

Langkah ketiga yang dilaksanakan dalam penelitian ini adalah melakukan pengamatan atau observasi. Dalam tahap ini, kegiatan utama yang dilakukan adalah mengadakan pengamatan terhadap pelaksanaan tindakan. Fungsi utama observasi adalah untuk mengetahui kesesuaian pelaksanaan tindakan dengan rencana, dan untuk mengetahui seberapa pelaksanaan tindakan yang sedang berlangsung dapat diharapkan akan memperoleh hasil yang diharapkan.

- Refleksi

Langkah keempat yang dilakukan dalam penelitian ini adalah mengadakan refleksi. Pada tahap ini data-data yang diperoleh melalui observasi dikumpulkan dan dianalisis. Berdasarkan hasil analisis, peneliti bersama tim pengajar dapat merefleksi diri tentang kegiatan yang dilakukan. Melalui refleksi diri tersebut dapat diketahui keberhasilan dan kekurangan yang dilakukan, sehingga biasa digunakan untuk memperbaiki dan menetapkan tindakan kelas selanjutnya.

\section{Hasil Penelitian}

Dengan melihat data hasil observasi berupa checklist dan tes formatif pada siklus I dan II dapat diketahui keaktifan dan prestasi belajar siswa kelas VIII SMP PGRI Karangjati pada mata pelajaran Dasar-dasar Elektronika melalui metode CTL.

1. Siklus I

a. Perencanaan tindakan

$\begin{array}{lr}\text { Sebelum } & \text { pembelajaran } \\ \text { dimulai peneliti } & \text { menyusun } \\ \text { silabus, Rencana Pelaksanaan } \\ \text { Pembelajaran (RPP), serta } \\ \text { menyiapkan instrument yang }\end{array}$

diperlukan diantaranya lembar observasi dan soal tes formatif.

b. Pelaksanaan tindakan Pelaksanaan belajar mengajar untuk siklus I dilaksanakan di kelas VIII dengan jumlah siswa 28 orang. Dalam hal ini peneliti bertindak sebagai guru. Adapun proses belajar mengajar mengacu pada RPP yang telah dipersiapkan dan diakhiri dengan melaksanakan evaluasi dan tes. Evaluasi dan tes formatif diberikan dengan tujuan untuk mengetahui tingkat keberhasilan siswa dalam kegiatan pembelajaran.

c. Pengamatan / Observasi

Pengamatan (Observasi) dilaksanakan bersamaan dengan proses pembelajaran. Keaktifan siklus 1 didapat kesimpulan sebagai berikut :

1) Siswa yang tidak aktif 2 anak persentasi $7,1 \%$

2) Siswa yang kurang aktif 5 anak persentasi $17,9 \%$

3) Siswa yang cukup aktif 14 anak persentasi $50 \%$

4) Siswa yang aktif 7 anak persentasi $25 \%$

d. Refleksi tindakan

Berdasarkan hasil observasi keaktifan siswa dapat diamati bahwa masih terdapat beberapa kelemahan pada pelaksanaan tindakan kelas siklus I yaitu:

1) Banyak siswa yang belum aktif mengikuti pelajaran

2) Siswa belum begitu antusias mengikuti jalannya diskusi kelas

3) Siswa masih belum berani menyampaikan pendapat, baik dalam diskusi kelompok maupun diskusi kelas 
4) Banyak siswa yang belum berani bertanya

2. Siklus II

a. Perencanaan tidakan

\begin{tabular}{lr}
\multicolumn{2}{c}{ Sebelum pembelajaran } \\
dimulai, peneliti $\begin{array}{r}\text { menyusun } \\
\text { silabus, Rencana Pelaksanaan }\end{array}$ \\
Pembelajaran (RPP), serta \\
menyiapkan instrument yang
\end{tabular} diperlukan, diantaranya lembar observasi dan soal tes formatif. Selain itu, pada siklus II direncanakan tindakan sesuai permasalahan pada siklus I yang merupakan perbaikan terhadap kekurangan siklus I antara lain:

1) Guru harus lebih komunukatif agar siswa lebih aktif dalam mengikuti pelajaran.

2) Memotivasi siswa agar lebih aktif dalam mengikuti jalannya diskusi kelas.

3) Memberi dorongan kepada siswa untuk berani menyampaikan pendapatnya.

4) Memotivasi siswa agar lebih berani bertanya.

b. Pelaksanaan tindakan Pelaksanaan belajar mengajar pada siklus II dilaksanakan pada tanggal $24 \mathrm{Mei}$ 2011 di kelas VIII dengan jumlah siswa 28 orang. Dalam hal ini peneliti bertindak sebagai guru. Adapun proses belajar mengajar mengacu pada RPP yang telah dipersiapkan dan diakhiri dengan melaksanakan evaluasi atau tes untuk mengetahui prestasi belajar siswa.

c. Pengamatan / Observasi

Pengamatan (Observasi) dilaksanakan bersamaan dengan proses pembelajaran. Keaktifan siklus II didapat kesimpulan sebagai berikut :
1) Siswa yang cukup aktif 11 anak persentasi 39,3\%

2) Siswa yang aktif 17 anak persentasi $60.7 \%$

d. Refleksi tindakan

1) Siswa sudah aktif mengikuti pelajaran

2) Sebagian besar siswa sudah berani menyampaikan pendapat

3) Banyak siswa yang sudah berani bertanya

4) Ada peningkatan keaktifan rata-rata kelas dan nilai ratarata kelas.

Dari kedua siklus tindakan kelas ini, peneliti sudah bisa mendapatkan gambaran kesimpulan dari kegiatan penelitian. Maka penelitian tidak dilanjutkan pada siklus berikutnya.

\section{SIMPULAN}

Berdasarkan hasil penelitian dan pembahasan pada bab IV mengenai "Upaya Peningkatan Keaktifan Belajar dan Prestasi Belajar Siswa Melalui Metode CTL (Contextual Teaching and Learning) Pada Mata Pelajaran Elektronika Pada Siswa Kelas VIII SMP PGRI Karangjati Ngawi" maka dapat diambil kesimpulan sebagai berikut :

1. Dengan menggunakan metode CTL (contextual teaching and learning) dapat meningkatkan keaktifan belajar dasar-dasar elektronika pada siswa kelas VIII SMP PGRI Karangjati.

2. Dengan menggunakan metode CTL (contextual teaching and learning) dapat meningkatkan prestasi belajar dasar-dasar elektronika pada siswa kelas VIII SMP PGRI Karangjati.

Hal ini dapat dilihat dari nilai rata-rata keaktifan siswa siklus I sebesar 15,82 naik pada siklus II menjadi 20,78 dan nilai rata-rata prestasi siklus I 
sebesar 75,35 naik pada siklus II menjadi 83,92.

\section{SARAN}

Berdasarkan kesimpulan di atas, maka peneliti memberi saran sebagai berikut:

1. Kepada Guru

Untuk meningkatkan keaktifan dan prestasi belajar siswa, guru hendaknya dapat menerapkan modelmodel pembelajaran yang lebih bervariasi guna mengembangkan daya pikir siswa khususnya untuk pelajaran elektronika. Misalnya dengan menerapkan model pembelajaran CTL (Contextual Teaching and Learning) yang telah dibuktikan bisa meningkatkan daya pikir siswa, sehingga keaktifan dan prestasi belajar siswa bisa meningkat.

2. Kepada Siswa

Dengan menggunakan metode pembelajaran CTL (Contextual Teaching and Learning) hendaknya siswa lebih kreatif lagi untuk berpikir sehingga dapat meningkatkan keaktifan dan prestasi belajar siswa.

3. Kepada Peneliti Lain

Untuk peneliti lain yang menerapkan pembelajaran melalui metode pembelajaran CTL (Contextual Teaching and Learning) hendaknya dilaksanakan pada materi dan subyek yang berbeda.

\section{DAFTAR PUSTAKA}

Akbar Hawadi, Reni. 2004. Akselerasi A-Z Informasi Program Percepatan Belajar dan Anak Berbakat Intelektual. Jakarta: PT. Grasindo Anggota Ikapi.

Faturrohman, Pupuh. 2007. Strategi Belajar Mengajar - Strategi Mewujudkan Pembelajaran Bermakna Melalui Penanaman
Konsep Umum \& Konsep Islami. Bandung: PT Refika Aditama.

http://www.anneahira.com/pengertianprestasi-belajar-menurut-paraahli.html

http://panduanskripsi.blogspot.com/2011/02/cirisiswa-aktif-pembelajaran.html

Komalasari, Kokom. 2010. Pembelajaran Kontekstual: Konsep dan Aplikasi. Bandung: PT Refika Aditama.

Mulyasa, E. 2004. Implementasi Kurikulum 2004. Bandung: PT Remaja Rosdakarya.

Nurul. 6 Juni 2010. Pendekatan Kontekstual (Contextual Teaching and Learning) dalam Pembelajaran Bahasa dan Sastra Indonesia.

(Online), (http://nurul07164429.wordpress. com/2010/06/06/pendekatankontekstual-contextual-teachingand-learningdalam-pembelajaranbahasa-dan-sastra-indonesia/).

Sanjaya, Wina. 2009. Penelitian Tindakan Kelas. Jakarta: Kencana.

Slameto. 2010. Belajar dan Faktorfaktor yang Mempengaruhi. Jakarta: Rineka Cipta.

Warsito, Bambang. 2008. Teknologi Pembelajaran. Jakarta: Rineka Cipta.

Wiyono, Bambang Budi. 2008. Penelitian Tindakan Kelas dan Penulisan Karya Ilmiah. Malang: Universitas Negeri Malang. 